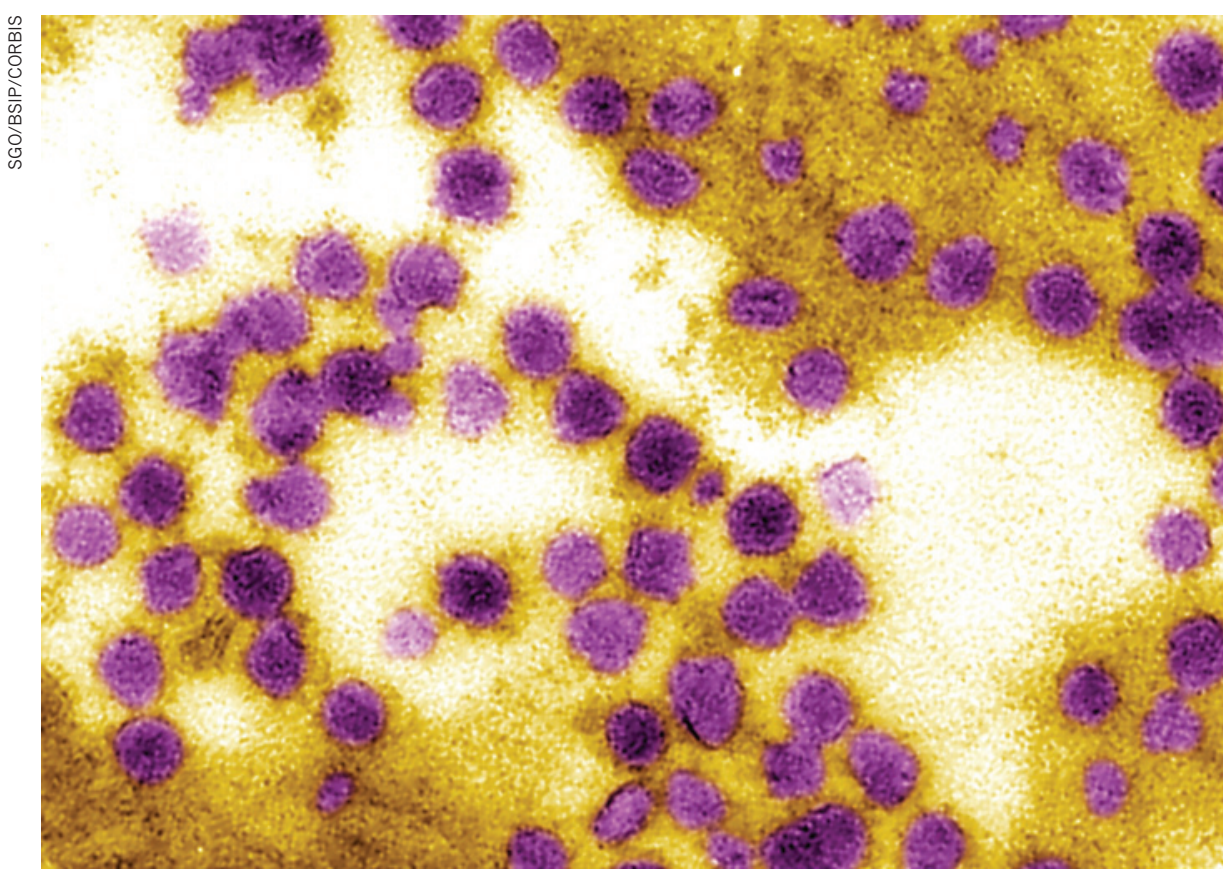

The fuzzy bodies of West Nile virus, which may target the kidneys.

\title{
EPIDEMIOLOGY
}

\section{The hidden threat of West Nile virus}

\section{Researchers probe possible link with kidney disease.}

\section{BY AMY MAXMEN}

$\mathrm{T}$ This year is on track to be the worst on record for West Nile virus in the United States. As of 11 September, more than 2,600 new cases, including 118 deaths, had been reported from across the country to the US Centers for Disease Control and Prevention (CDC) in Atlanta, Georgia.

Symptoms of the mosquito-borne disease range from none (in most people) to lifethreatening brain inflammation, and it can leave survivors with long-term disabilities including paralysis and fatigue. Researchers are now investigating suggestions that even mild infections may leave another lasting burden - kidney disease.

"We are early in our understanding, but this really worries me," says Kristy Murray, an epidemiologist and clinical researcher at Baylor College of Medicine in Houston, Texas, who has found hints that the virus may persist in the kidney long after the initial infection. This week she is moving her work on the long-term consequences of West Nile to a new biosecurity-level-3 laboratory at nearby Texas Children's Hospital, where she will explore a link between the virus and kidney disease.

Researchers agree that the claim needs to be investigated. "If Murray's findings are true, we have to think about what to do with all of these people with mild infections," says William Reisen, an entomologist at the Center for Vectorborne Diseases at the University of California, Davis. But Murray is also facing scepticism, which she hopes to address in the latest phase of her research.

Murray's quest began at a meeting of West Nile survivors in Texas in 2009, where a man in his early fifties who had recovered from a 2003 infection announced that he had kidney disease. He was dead within a year. To Murray, his illness brought to mind studies in which researchers had detected and cultured the virus in kidney tissue from laboratory animals long after they were infected with West Nile.

Murray collected urine samples from 25 survivors of West Nile and found that five had viral RNA in their urine well after they had been infected ${ }^{1}$, suggesting that the virus might have established itself in their kidneys. To examine whether the virus might harm kidneys over time, Murray's team then looked for indicators of long-term kidney disease, such as excess protein in the urine, in samples from 139 people, most of whom were infected with the 2003 strain of the virus. She reported ${ }^{2}$ in July that $40 \%$ of that group showed signs of long-term kidney disease.

However, Lyle Peterson, director of the division of vector-borne infectious diseases at the $\mathrm{CDC}$, sees no cause for alarm given the current evidence. He points out that Murray's latest study did not include a control group, and that a CDC study of some West Nile survivors in Colorado found no evidence of viral RNA in the subjects' urine ${ }^{3}$.

Michael Busch, director of the Blood Systems Research Institute in San Francisco, California, told Nature that his team had also failed to find viral RNA, even though it had tested some of the same urine samples that Murray used. "Until multiple labs find the same results from the same blinded samples, everything must be taken with a grain of salt," says Busch.

Murray maintains that there is an art to detecting RNA in urine. The single-stranded fragments are easily broken apart by enzymes in the fluid and by freezing and thawing when samples are shipped and stored. By contrast, samples that had travelled for just one hour from Murray's lab to the University of Texas Medical Branch (UTMB) in Galveston for independent testing corroborated her
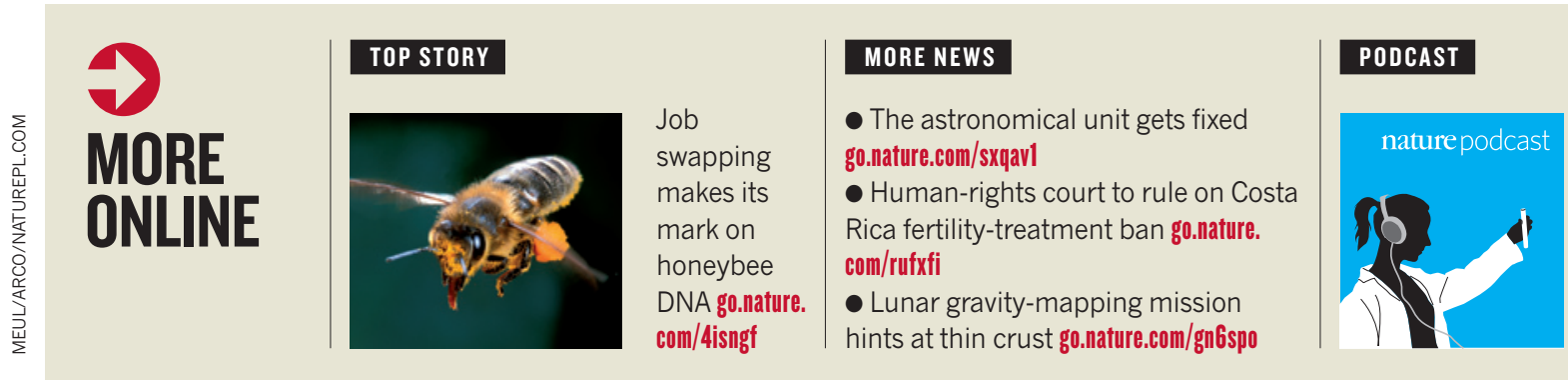

The brain never rests, our gut instinct to cooperate and electricity from heat go.nature.com/ gww192 
- findings ${ }^{1}$. Still, she says, she was shaken by the criticism. "I was starting to feel crazy. I wondered if I was committing career suicide."

Murray has regained her confidence. In one electron micrograph image, not yet published, she points to a group of fuzzy spheres that look like West Nile virus in a cell found in the urine of a woman who suffered an infection in 2003. Other particles in urine can look like small, fuzzy balls, critics note. But Murray hopes that within a year she will have evidence that will silence the sceptics. With her new lab and a four-year grant from the National Institutes of Health, she plans to recruit 440 people - half of whom had West Nile - to a study to look for kidney disease. By next month she also plans to try to isolate and grow the virus from urine. Murray says it's not just a matter of defending her hypothesis, and others agree. "If we know this is a problem, we would know to monitor West Nile patients, and as soon as you saw some kidney enzymes acting abnormally, you could start to think about ways to prevent the progression of kidney disease," says
Frederick Murphy, a virologist at the UTMB.

No drugs have been shown to be effective against West Nile, for either the immediate infection or the long-term effects. "We need to start thinking about how to treat it," Murray says. If her suspicions prove correct, that need will soon seem far more urgent than it did before.

1. Murray, K. et al. J. Infect. Dis. 201, 2-4 (2010).

2. Nolan, M. S. et al. PLoS ONE 7, e40374 (2012).

3. Gibney, K. B. et al. J. Infect. Dis. 203, 344-347 (2011).

\section{NANOTECHNOLOGY}

\section{Nano-safety studies urged in China}

\section{Exposure surveys and stronger regulations are required for the industry to thrive, researchers say.}

\section{BY JANE QIU IN BEIJING}

$\mathrm{H}$ ere is a recipe for anxiety: take China's poorly enforced chemical-safety regulations, add its tainted record on product safety and stir in the uncertain risks of a booming nanotechnology industry.

As an antidote to this uneasy mixture, the country should carry out more-extensive safety studies and improve regulatory oversight of synthetic nanomaterials, leading Chinese researchers said at the 6th International Conference on Nanotoxicology in Beijing this month. "This is the only way to maintain the competitiveness of China's nanotechnology sector," says Zhao Yuliang, deputy director of the Chinese Academy of Sciences' National Center for Nanoscience and Technology (NCNST) in Beijing. "We certainly don't want safety issues to become a trade barrier for nano-based products."

China's investment in nanotechnology has grown rapidly during the past decade, and its tally of patent applications in the field has surpassed those of Europe and the United States (see 'Patent boom'). But only $3 \%$ of the investment is used for safety studies, says Zhao, compared with about $6 \%$ of federal nanotechnology funding in the United States. "The situation must be changed soon," he says.

Nanoparticles - which measure from 1 to 100 nanometres in diameter - are chemically different from their corresponding bulk mat-

$\rightarrow$ NATURE.COM read more from China at: nature.com/nchina
In 2009, researchers claimed that nanoparticles were responsible for lung damage in seven workers at a printing factory in Beijing, two of whom subsequently died (see Nature 460, 937; 2009). Volatile organic compounds may actually have been to blame, says Andre $\mathrm{Nel}$, a nanotoxicologist at the University of California, Los Angeles, but such incidents could easily damage the fledgling industry's reputation. For now, however, the Chinese public remains unconcerned: in a survey led by Wang Guoyu, an ethicist at the Dalian University of Technology, nearly $80 \%$ of some 6,000 Chinese respondents said that they are not worried about the safety of nanoparticles.

Researchers at the meeting said that better safety testing was needed for products containing nanoparticles that can be absorbed by

\section{PATENT BOOM}

China has taken a global lead in filing nanotechnology patents over the past decade.

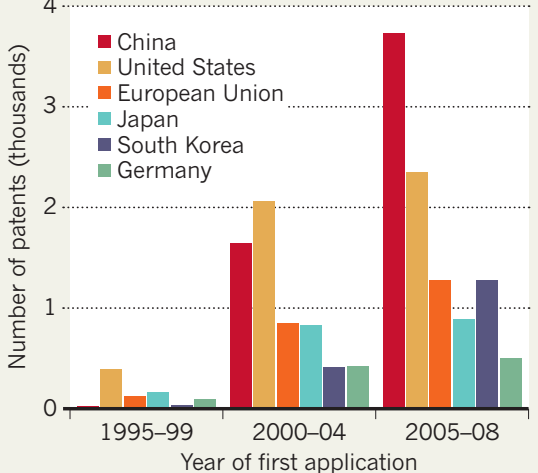
ing to dozens of characteristics, such as size, surface area and coating. the body, such as food and cosmetics in which nanoparticles provide specific colours or textures. But occupational exposure among workers handling the materials may present the greatest risks: China's workplace safety rules are not always implemented, and they set no specific limits for handling nanoparticles.

"The main challenge is to tease out what characteristics make some nanoparticles hazardous," says Zhao. To address that question, Chinese researchers will next year join forces with colleagues in Europe, the United States and Brazil in a $€ 13$-million (US\$17-million) project called Nanosolutions, to develop a nano-safety classification system based on material characteristics, toxicity studies and bioinformatics data. Initially focusing on 30 or so materials, such as carbon nanotubes, and nanoparticles of titanium dioxide and silver, the team will use high-throughput screening to identify the most toxic, and then investigate their biological effects in animal studies.

The data will be used to develop computer software to predict the potential hazards of other nanomaterials - a useful tool for industry and regulators around the world, and "essential to any progress in risk assessment", says Kai Savolainen, a researcher at the Finnish Institute of Occupational Health in Helsinki, who leads the project. "It will also help the industry to design safe nanomaterials from the outset."

Studying factory workers who are exposed to nanomaterials could yield further insights. With Chinese exposure levels likely to be much higher than those in Western factories, such surveys are ideally placed to quantify the risks involved, says Dhimiter Bello, an expert in occupational health at the University of Massachusetts in Lowell. Since last year, a team led by the NCNST's Chen Chunying has been monitoring chemical exposure levels, including those of nanomaterials, in three factories that have varying safety practices. The researchers hope that their data will help the government to draw up regulations covering nanoparticles in the workplace.

As China's exports are increasingly likely to carry nanotechnology inside them, better regulation is "important not only for safeguarding people, but for the public acceptance of nanotechnology worldwide", says Nel. - 